\title{
Evaluation of Performance of Detection of IgG and IgM Antibody Against Spike Protein of SARS-CoV-2 by a Rapid Kit in a Real-Life Hospital Setting
}

\section{Monica Irungbam}

Department of Biochemistry, Maulana Azad Medical College and Associated Hospitals, New Delhi, India, PIN110002

\section{Anubhuti Chitkara}

Department of Biochemistry, Maulana Azad Medical College and Associated Hospitals, New Delhi, India, PIN110002

\section{Vijay Kumar Singh}

Multidisciplinary Research Unit (MRU). Maulana Azad Medical College and Associated Hospitals, New Delhi, India, PIN-110002.

\section{Subash Chandra Sonkar}

Multidisciplinary Research Unit (MRU). Maulana Azad Medical College and Associated Hospitals, New Delhi, India, PIN-110002.

\section{Abhisekh Dubey}

Department of Biochemistry, Maulana Azad Medical College and Associated Hospitals, New Delhi, India, PIN110002

\section{Astha Bansal}

Department of Biochemistry, Maulana Azad Medical College and Associated Hospitals, New Delhi, India, PIN110002

\section{Ritika Shrivastava}

Department of Biochemistry, Maulana Azad Medical College and Associated Hospitals, New Delhi, India, PIN110002

\section{Binita Goswami}

Department of Biochemistry, Maulana Azad Medical College and Associated Hospitals, New Delhi, India, PIN110002

\section{Vikas Manchanda}

Department of Microbiology, Maulana Azad Medical College and Associated Hospitals, New Delhi, India, PIN110002

\section{Sonal Saxena}

Department of Microbiology, Maulana Azad Medical College and Associated Hospitals, New Delhi, India, PIN110002

\section{Ritu Saxena}

Emergency Department, Lok Nayak Jai Prakash (LNJP) Hospital New Delhi, India, PIN-110002

\section{Sandeep Garg}

Department of Medicine, Lok Nayak Jai Prakash (LNJP) Hospital New Delhi, India, PIN-110002

\section{Farrah Hussain}


Department of Anesthesiology, Lok Nayak Jai Prakash (LNJP) Hospital New Delhi, India, PIN-110002

\section{Tanmaya Talukdar}

Department of TB \& Chest Diseases / Pulmonary Medicine, Lady Hardinge Medical College (LHMC), New Delhi, India, PIN-110002.

\section{Dinesh Kumar}

Food Safety and Standards Authority of India, Ministry of Health and Family Welfare-MoHFW, New Delhi, India, PIN-110002

\section{Bidhan Chandra Koner ( $\sim$ bckoner@hotmail.com )}

Department of Biochemistry, Maulana Azad Medical College and Associated Hospitals, New Delhi, India, PIN110002

\section{Research Article}

Keywords: SARS-CoV-2, COVID-19, chemiluminesence Analysis, Rapid Antibody Test, Spike protein's receptorbinding domain (RBD), spike surface glycoprotein (Spike Protein), Nuclear capsid Protein (NCP)

Posted Date: September 27th, 2021

DOl: https://doi.org/10.21203/rs.3.rs-898232/v1

License: (c) (i) This work is licensed under a Creative Commons Attribution 4.0 International License. Read Full License 


\section{Abstract \\ Background}

Antibody testing are often used for serosurveillance of COVID-19. ELISA and Chemiluminesence based antibody test are quiet sensitive and specific for such serological testing. Rapid antibody tests are developed and effectively used for this purpose. But their diagnostic efficiency needs to be evaluated. So, the present study was conducted in a dedicated COVID-19 hospital in Delhi, India to evaluate the diagnostic efficacy of a Rapid antibody kit for COVID19.

\section{Material and Method}

: Sixty COVID-19 confirmed cases by RT-PCR were recruited and categorized as early, intermediate and late cases based on the number of days of their first RT-PCR + ve tests, 20 subjects in each category. Twenty samples from pre-covid era were taken as controls. IgM and IgG antibodies against RBD of spike protein (S) of SARS-CoV2 virus were detected by Rapid antibody test and compared with total antibody against the nucleocapsid $(\mathrm{N})$ antigen of SARS-CoV-2 by Electrochemiluminescence based Immunoassay (ECLIA).

\section{Results}

The detection IgM against Receptor binding domain (RBD) of spike protein by rapid kit was 0-37.5\% sensitive and 0-100\% specific for diagnosis of SARS-CoV-2 infection. However, efficacy of detection of IgG by rapid kit was 87$89 \%$ sensitive and $75-100 \%$ specific when compared with total antibody against $\mathrm{N}$ antigen measured by ECLIA based immunoassay.

\section{Conclusion}

It can be concluded that detection of IgM against RBD of S protein by rapid kit is not effective but IgG detection can be used as an effective diagnostic tool for SARS-COV-2 infection.

\section{Introduction:}

The world is facing the outbreak of coronavirus disease-2019 (COVID-19) which has become a public health event of international concern (1-4). Accurate and rapid diagnosis of SARS-CoV-2 infection is needed for prompt and effective patient care. The quantitative reverse-transcriptase polymerase chain reaction (qRT-PCR) is the clinically accepted standard method for molecular diagnosis of SARS-CoV-2 detection. Alternatively, rapid antigen test (RAT) kit is also used for Covid-19 diagnosis. However, RT-PCR test has 70\% sensitivity and $95 \%$ specificity and pose risks related to specimen collection and sample handling $(5,6)$. A recent meta-analysis revealed that the average sensitivity and specificity of RAT for SARS-CoV-2 were $56.2 \%$ and $99.5 \%$, respectively (7). These tests may also be falsely negative due to quality of sample or timing of carrying the test as viral load in upper respiratory tract secretions peak in the first week of symptoms, but may decline below the limit of detection in those presenting later. In individuals who have recovered, RT-PCR provides no information about prior exposure or immunity. Addressing this concern, various researchers developed a solution to minimize these risks by assaying IgG and 
IgM against the virus. Serological testing with good detection performance, can be used as supplementary diagnosis of COVID-19 suspect cases with negative nucleic acid test result (8). Also, to diagnose patients after the acute phase of the infection or with atypical clinical presentation with no nasopharyngeal shedding of the virus, serology testing is very useful (8-10). In addition, serological testing provides a useful surveillance tool to track seroprevalence, assess the immune status in a community, and may also be useful for decisions on lockdown entry-exit strategies (11).

The human body produces specific antibodies after the virus invades. The specific lgM antibody appears first, and then the titer of IgG antibody rises. Thus, the detection of IgM and IgG is believed to be another important diagnostic tool along with RT-PCR and RAT. The tests presently available detects anti-SARS-CoV-2 immunoglobulins which are usually formed in the patient's body at the earliest by 1 week, and on average within $2-3$ weeks from the onset of infection $(6,12)$.

Various SARS-CoV-2 serological tests using different targeted antigenic proteins have been available now. Some of them use whole virus lysate, recombinant full S (spike) or N (nucleocapsid) proteins, peptides of the $\mathrm{N}$ or specific domains S1, S2 or RBD (receptor-binding domains) of the S protein. Studies have shown that S and N proteins of the virus are the most immunogenic, and these serological tests can be performed with various techniques $(13$, 14). ELISA and Chemiluminesence are considered standard methods for the same. Rapid antibody kits are also available as a point of care testing tool. This rapid serological test is a simple procedure, needs no special equipment, is relatively cheap and gives fast results. But utility of this type of rapid antibody detection kit in diagnosis of COVID-19 in real life hospital settings is warranted. This study is conducted to evaluate the sensitivity and specificity of a rapid antibody kit that detects IgM and IgG separately by comparing with total antibody detection by chemiluminesence method.

\section{Methodology:}

The Observational study was conducted in the Department of Biochemistry in collaboration with Multidisciplinary Research Unit, Maulana Azad Medical College and Department of Medicine Lok Nayak Hospital, New Delhi, University of Delhi, Delhi, India after ethical approval. Study ethical approval Number is F.1/IEC/MAMC/(81/09/2020/No: 278) Dated: 24/11/2020. Written informed consent was obtained from all subjects and/or their legal guardian and all methods were carried out in accordance with relevant guidelines and regulations.

\section{Sample Collection:}

All the subjects included in this study were COVID-19 confirmed cases by RT-PCR at different stages of disease. Blood samples sent for other biochemical tests were used and no separate sample was collected for the study. Patients were categorized as early cases if they were recruited with in the first week, as intermediate if taken between 8-14 days of RT-PCR and late if $>14$ days of their first RT-PCR + ve tests. Recruitment continued till 20 samples were collected in each group. Twenty non COVID-19 samples of pre-COVID-19 era were used as controls. Samples were run on fully automated Cobas e411, by Roche diagnostics using Elecsys ${ }^{\circledR}$ Anti-SARS-CoV-2, based on electrochemiluminescence $(E C L)$ immunoassay for total antibody against the nucleocapsid $(\mathrm{N})$ antigen of SARS-CoV-2. The cut-off indice for positive immunoassay was 1.0 (arbitrary unit) by this method. Immunoquick COVID-19 kit used in this study was produced by standard analytical laboratory, New Delhi, India. It is an 
immunochromatographic test for detection of IgM and IgG antibodies to RBD of spike protein (S) of SARS-CoV 2 virus from human serum/plasma/whole blood.

\section{Statistical Analysis:}

Specificity, sensitivity, negative predictive value (NPV) and positive predictive value (PPV) were calculated for each assay. The strength of the agreement of the two methods was calculated by using the Cohen Kappa index. Results were interpreted according to the following kappa values: i) $0.01-0.20$, slight agreement; ii) $0.21-0.40$, fair agreement; iii) $0.41-0.60$, moderate agreement; iv) 0.61-0.80, substantial agreement; and v) 0.81-1.00, perfect agreement. $P<0.05$ was considered statistically significant.

\section{Results:}

Of the 60 patients enrolled in the study, patients were having mild, moderate or severe clinical course and were divided into three groups according to the duration of the RT PCR results i.e. between 0-7 days, 8-14 days and > 14 days and compared. Male: female ratio was 14:6 in group 1, 16:4 in group II and 15:5 in group III. Difference between these groups for male: female ration was statistically insignificant. Twenty samples of pre-covid era were taken as controls. The distribution of results of total antibody positive (level $>1.0)$ and negative $($ level $<1.0)$ against N protein of SARS Cov-2 virus and archieved pre-covid era Non-covid samples are presented in Table 1.

Table 1

Distribution of total antibody against nucleocapsid protein of SARS-CoV2 test results at $0-7$ days, $8-14$ days and > 14 days of RT-PCR + ve confirmed Covid-19 cases and pre-COVID-19 era controls.

\begin{tabular}{|c|c|c|c|c|c|}
\hline & \multicolumn{3}{|c|}{ COVID Confirmed cases by RT PCR } & \multirow[t]{2}{*}{ Non-Covid (Pre-Covid Samples) } & \multirow{2}{*}{$\begin{array}{l}\text { Fischer Exact test } \\
\text { (p) }\end{array}$} \\
\hline & $0-7$ days & $8-14$ days & $>14$ days & & \\
\hline ECLIA $>1.0$ & 16 & 19 & 20 & 0 & \multirow[t]{2}{*}{$p<0.00001$} \\
\hline$E C L I A<1.0$ & 4 & 1 & 0 & 20 & \\
\hline
\end{tabular}

\section{Discussion:}

The present study was designed to evaluate the diagnostic efficacy of Rapid antibody kit for COVID-19. Among the diagnostic immunoassay methods, chemiluminesence based immunoassay is considered to be very sensitive and

effective. In the present study, diagnostic efficacy of total antibody assay against nucleocapsid protein during 0-7 days, 8-14 days and after 14 days of PCR positive tests were evaluated.

Tables 1 and 2 shows that during first seven days after PCR positivity, the sensitivity, specificity, PPV and NPV of ECLIA based antibody assay were 80,100, 100 and 83.3\% respectively, between 8-14 days after PCR positivity these parameters were 95, 100, 95 and 95.2\% respectively and for more than fourteen days after PCR positivity, these indices were $100 \%$. This indicates that ECLIA is a very effective diagnostic tool for COVID-19 and its efficacy after 7 days is very close to that of RT-PCR. Even within 7 days, it was found to be very effective. So, for comparison of any other antibody testing method, ECLIA based immunoassay can be considered as a standard method. 
Table 2

Accuracy indices of total antibody assay against NC protein by ECLIA at $0-7,8-14$ and $>14$ days of Covid diagnosis by RT-PCR.

\begin{tabular}{|llll|}
\hline & $\begin{array}{l}\text { Within } \mathbf{0 - 7} \text { days of RT-PCR } \\
\text { report }\end{array}$ & $\begin{array}{l}\text { Within 8-14 days of RT-PCR } \\
\text { report }\end{array}$ & $\begin{array}{l}\text { More than 14 days of RT-PCR } \\
\text { report }\end{array}$ \\
\hline Sensitivity\% & $80 \%$ & $95 \%$ & $100 \%$ \\
\hline Specificity\% & $100 \%$ & $100 \%$ & $100 \%$ \\
\hline PPV\% & $100 \%$ & $95 \%$ & $100 \%$ \\
\hline NPV\% & $83.3 \%$ & $95.2 \%$ & $100 \%$ \\
\hline
\end{tabular}

For assessment of servo-prevalence, most of the authorities recommend antibody assay either by ELISA or CLIA based methods. The manufacturers of rapid antibody assays claim that rapid test is also effective in serosurveillance particularly in remote areas where lab facilities are not there. However, the diagnostic efficacy of these rapid antibody kit has also been evaluated in standard laboratory conditions $(15,16)$. But not in real life hospital settings treating COVID-19 patients. There is limited data to prove their efficacy in hospital setting. So, in this study we tried that in a dedicated COVID hospital.

Tables $3 \& 4$ shows that the total assay of IgM has very limited sensitivity during $0-7$ days i.e. $37.5 \%$, with in $8-14$ days it is $31.6 \%$ although specificity and PPV was cent percent. NPV was found to be 28 and $7.14 \%$ and Cohen's kappa was 0.1935 and 0.044 respectively. After 14 days, as expected IgM antibody by rapid kit was undetectable because of class switching of antibody. Hence, we conclude that IgM detection by rapid kit is not at all effective as a diagnostic tool for COVID-19.

Table 3

$2 \star 2$ Table showing distribution of positive and negative antibody test results by rapid test kit and ECLIA method on samples collected from Covid patients at 0-7 days, 8-14 days and after 14 Days of + ve RT-PCR.

\begin{tabular}{|c|c|c|c|c|c|c|c|c|}
\hline & \multicolumn{8}{|c|}{ Total antibody assayed by Electrochemiluminesence method } \\
\hline & & & $\begin{array}{l}\text { With in } 0 \\
\text { PCR }\end{array}$ & Days of RT- & $\begin{array}{l}\text { With in } 8 \\
\text { PCR }\end{array}$ & Days of RT- & $\begin{array}{l}\text { After } 14 \\
\text { PCR }\end{array}$ & ys of RT- \\
\hline \multirow{5}{*}{$\begin{array}{l}\text { Rapid } \\
\text { test }\end{array}$} & & & Positive & Negative & Positive & Negative & Positive & Negative \\
\hline & \multirow[t]{2}{*}{$\lg M$} & Positive & 06 & 00 & 06 & 00 & 00 & 00 \\
\hline & & Negative & 10 & 04 & 13 & 01 & 20 & 00 \\
\hline & \multirow[t]{2}{*}{$\lg G$} & Positive & 14 & 01 & 18 & 00 & 17 & 00 \\
\hline & & Negative & 02 & 03 & 01 & 01 & 02 & 01 \\
\hline
\end{tabular}


Table 4

Accuracy indices of IgM and IgG antibody (against RBD of spike protein of SARS-CoV2 virus) by rapid test for the diagnosis of Covid-19 (calculated by taking total antibody level estimated by electrochemiluminesence as standard method).

\begin{tabular}{|c|c|c|c|c|c|c|c|c|}
\hline & \multicolumn{4}{|c|}{ Diagnostic accuracy of IgM by rapid kit } & \multicolumn{4}{|c|}{ Diagnostic accuracy of IgG by rapid kit } \\
\hline & $\begin{array}{l}\text { Sample } \\
\text { collected } \\
\text { within } \\
0-7 \\
\text { days of } \\
+ \text { ve RT- } \\
\text { PCR }\end{array}$ & $\begin{array}{l}\text { Sample } \\
\text { collected } \\
\text { within } \\
\text { 8-14 } \\
\text { days of } \\
+ \text { ve RT- } \\
\text { PCR }\end{array}$ & $\begin{array}{l}\text { Sample } \\
\text { collected } \\
\text { withafter14 } \\
\text { days of + } \\
\text { ve RT-PCR }\end{array}$ & $\begin{array}{l}\text { Pre- } \\
\text { Covid } \\
\text { samples }\end{array}$ & $\begin{array}{l}\text { Sample } \\
\text { collected } \\
\text { within } \\
0-7 \\
\text { days of } \\
+ \text { ve RT- } \\
\text { PCR }\end{array}$ & $\begin{array}{l}\text { Sample } \\
\text { collected } \\
\text { within } \\
\text { 8-14 } \\
\text { days of } \\
+ \text { ve RT- } \\
\text { PCR }\end{array}$ & $\begin{array}{l}\text { Sample } \\
\text { collected } \\
\text { with } \\
\text { after14 } \\
\text { days of } \\
\text { + ve RT- } \\
\text { PCR }\end{array}$ & $\begin{array}{l}\text { Pre- } \\
\text { Covid } \\
\text { samples }\end{array}$ \\
\hline $\begin{array}{l}\text { Sensitivity } \\
\%\end{array}$ & 37.5 & 31.6 & 0 & 100 & 87.5 & 94.73 & 89.47 & 100 \\
\hline $\begin{array}{l}\text { Specificity } \\
\%\end{array}$ & 100 & 100 & 0 & 100 & 75 & 100 & 100 & 100 \\
\hline $\begin{array}{l}\text { Positive } \\
\text { Predictive } \\
\text { value } \\
\text { (PPV) \% }\end{array}$ & 100 & 100 & 0 & 100 & 93 & 100 & 100 & 100 \\
\hline $\begin{array}{l}\text { Negative } \\
\text { Predictive } \\
\text { value } \\
\text { (NPV) \% }\end{array}$ & 28 & 7.14 & 0 & 100 & 60 & 50 & 33.3 & 100 \\
\hline $\begin{array}{l}\text { Cohen's } \\
\text { Kappa }(k)\end{array}$ & 0.1935 & 0.044 & 0 & & 0.5714 & 0.6428 & 0.459 & \\
\hline
\end{tabular}

As shown in Table 3 and 4, detection of IgG by rapid kit on 0-7 days, 8-14 days and after 14 days was $87.5,94.7$ and $89.5 \%$ respectively and specificity was 75,100 and $100 \%$ respectively. PPV and NPV and Cohen's kappa was 93,100 and $100 \% \& 60,50$ and $33.3 \%$ and $0.5714,0.6428$ and 0.459 respectively. This indicates that IgG detection is effective enough in the diagnosis of Covid-19 in hospital setting. Even within 0-7 days, its sensitivity and specificity were high, indicating a possible early class-switching of antibody against RBD of spike protein. These observations go against the contention that antibody detection or assay best suits for the serosurvillence and not for the diagnosis. From this, we conclude that efficacy of IgG against Receptor binding domain (RBD) of spike protein is as effective as that by CLIA and can be utilized in hospital setting. However, combining IgM detection along with lgG is not improving the diagnostic efficacy and hence is a mere wastage of resources. So, we recommend IgG assay by rapid kit in the diagnosis of COVID-19 for the screening of suspected patients where RTPCR or CLIA based antibody assay facility is not there.

However, the limitation of the present study is that while evaluating Rapid test, we evaluated detection of antibody against RBD of spike protein of SARS-CoV2 virus but taken assay of total antibody against a different i.e. Nucleocapsid $(\mathrm{N})$ protein as our standard reference method.

\section{Declarations}

Conflict of Interests: 
The authors declare that there are no conflict of interests.

\section{Authors Contributions:}

Conceived and designed the experiments: Bidhan Chandra Koner, Binita Goswami, Anbhuti, Subash C. Sonkar, Sandeep Garg, Farrah Hussain, Sonal Saxena, Vikas Manchanda. Carried out the experiments: Monica Irungbam, Vijay K. Singh, Aastha Bansal, Abhishek Dubey, Subash C. Sonkar, and Srivastava Reetika. Collection of clinical samples: Monica Irungbam, Vijay K. Singh, Aastha Bansal, Abhishek Dubey. Performed the analysis: Anubhuti, Subash C. Sonkar, Binita Goswami, Bidhan C. Koner. Analyzed the data: Anubhuti, Subash C. Sonkar, Binita Goswami, Bidhan C. Koner. Wrote and finalized the manuscript. Monica Irungbam, Anubhuti, Subash C. Sonkar, Binita Goswami, Bidhan C. Koner. Contributed resources: Bidhan C. Koner, Dinesh Kumar, Tanmay Talukdar.

All authors read and approved the final manuscript.

\section{Acknowledgement:}

The infrastructure of multidisciplinary research unit (MRU) at Maulana Azad Medical College, New Delhi which is funded by the Department of Health Research, Ministry of Health and Family Welfare, Govt. of India was used for carrying out the experiments for the study.

\section{References}

1. Nilsson AC, Holm DK, Justesen US, Gorm-Jensen T, Andersen NS, Øvrehus A, et al. Comparison of six commercially available SARS-CoV-2 antibody assays-Choice of assay depends on intended use. Int $\mathrm{J}$ Infect Dis. 2021 Feb 1;103:381-8.

2. He J, Hu P, Gao Y, Zheng S, Xu C, Liu R, et al. Comparison and application of different immunoassay methods for the detection of SARS-CoV-2. J Med Virol. 2020 Nov 14;92(11):2777-84.

3. Dubey A, Bansal A, Sonkar SC, Goswami B, Makwane N, Manchanda V, Koner BC. In-house assembled protective devices in laboratory safety against SARS-nCoV-2 in clinical biochemistry laboratory of a COVID dedicated hospital. medRxiv 2020.08.24.20155713; doi: https://doi.org/10.1101/2020.08.24.20155713.

4. Dubey A, Kotnala G, Mandal TK, Sonkar SC, Singh VK, Guru SA, Bansal A, Irungbam M, Husain F, Goswami B, Kotnala RK, Saxena S, Sharma SK, Saxena KN, Sharma C, Kumar S, Aswal DK, Manchanda V, Koner BC. Evidence of the presence of SARS-CoV-2 virus in atmospheric air and surfaces of a dedicated COVID hospital. J Med Virol. 2021 Sep;93(9):5339-5349. doi: 10.1002/jmv.27029.

5. Feng W, Newbigging AM, Le C, Pang B, Peng H, Cao Y, et al. Molecular Diagnosis of COVID-19: Challenges and Research Needs. Anal Chem. 2020 Aug 4;92(15):10196-209.

6. Afzal A. Molecular diagnostic technologies for COVID-19: Limitations and challenges. J Adv Res. 2020 Nov 1;26:149-59.

7. Pray IW, Ford L, Cole D, Lee C, Bigouette JP, Abedi GR, et al. Performance of an Antigen-Based Test for Asymptomatic and Symptomatic SARS-CoV-2 Testing at Two University Campuses - Wisconsin, SeptemberOctober 2020. MMWR Morb Mortal Wkly Rep. 2021 Jan 1;69(5152):1642-7.

8. Long Q-X, Liu B-Z, Deng H-J, Wu G-C, Deng K, Chen Y-K, et al. Antibody responses to SARS-CoV-2 in patients with COVID-19. Nat Med. 2020 Jun 29;26(6):845-8. 
9. Long Q-X, Tang X-J, Shi Q-L, Li Q, Deng H-J, Yuan J, et al. Clinical and immunological assessment of asymptomatic SARS-CoV-2 infections. Nat Med. 2020 Aug 18;26(8):1200-4.

10. Young BE, Ong SWX, Kalimuddin S, Low JG, Tan SY, Loh J, et al. Epidemiologic Features and Clinical Course of Patients Infected With SARS-CoV-2 in Singapore. JAMA. 2020 Apr 21;323(15):1488-94.

11. Noh JY, Yoon JG, Seong H, Choi WS, Sohn JW, Cheong HJ, et al. Asymptomatic infection and atypical manifestations of COVID-19: Comparison of viral shedding duration. J Infect. 2020 Nov 1;81(5):816-46.

12. Alsaud AE, Nair AP, Matarneh AS, Sasi S, El Hassan R, Khan F, et al. Case Report: Prolonged Viral Shedding in Six COVID-19 Patients. Am J Trop Med Hyg. 2021 Feb 24;104(4):1472-5.

13. Parai D, Dash GC, Choudhary HR, Peter A, Rout UK, Nanda RR, et al. Diagnostic accuracy comparison of three fully automated chemiluminescent immunoassay platforms for the detection of SARS-CoV-2 antibodies. J Virol Methods. 2021 Jun 1;292:114121.

14. Jacofsky D, Jacofsky EM, Jacofsky M. Understanding Antibody Testing for COVID-19. J Arthroplasty. 2020 Jul 1;35(7S):S74-81.

15. Saif LJ. Coronavirus immunogens. Vet Microbiol. 1993 Nov;37(3-4):285-97.

16. Duan L, Zheng Q, Zhang H, Niu Y, Lou Y, Wang H. The SARS-CoV-2 Spike Glycoprotein Biosynthesis, Structure, Function, and Antigenicity: Implications for the Design of Spike-Based Vaccine Immunogens. Front Immunol. 2020 Oct 7;11:576622.

17. Li Z, Yi Y, Luo X, Xiong N, Liu Y, Li S, et al. Development and clinical application of a rapid IgM-lgG combined antibody test for SARS-CoV-2 infection diagnosis. J Med Virol. 2020 Sep 13;92(9):1518-24.

18. Zhang C, Zhou L, Liu H, Zhang S, Tian Y, Huo J, et al. Establishing a high sensitivity detection method for SARS-CoV-2 IgM/lgG and developing a clinical application of this method. Emerg Microbes Infect. 2020 Dec $1 ; 9(1): 2020-9$. 